Western University

Scholarship@Western

7-2009

Processes of Alienation: Marx, Orff and Kodaly

Cathy Benedict

Follow this and additional works at: https://ir.lib.uwo.ca/musiceducationpub

Part of the Education Commons, and the Music Commons 


\title{
Processes of alienation: Marx, Orff and Kodaly
}

\section{Cathy Benedict}

New York University, 300 W. 108th \#15A, New York, NY, USA 10025 cathy.benedict@nyu.edu

Using Marx as a lens through which to interrogate music methodology, in particular those espoused by Orff and Kodaly, this article suggests that rather than the free play and creativity Orff and Kodaly intended, the implementation of these methods in a strict and unmindful manner, often alienates both teacher and student from musicking. Thus these methods have become more real than the music itself and as such, music making within them is abstracted from the use-value of musicking and consequently exchanged as a commodity. The article explains how methods become a form of production that serves to reproduce systems of domination as well as a very particular form of cultural capital. This lens also allows us to realise that, as we move farther away from the process of inquiry originally embedded in the conception and construction of these musical engagements, the educative process becomes more and more myopic. This, in turn, determines, delineates and narrows possibilities of and for meaningful learning.

\begin{abstract}
Understanding methodology as a social rather than a technical question requires a second look at the kind of selves cultivated by both schools and universities. The desire for a 'literal' practicality in educational coursework is not so much a dismissal of theory as it is an ushering in of stability and control and thus for a particular notion of the stable self. (Britzman, 1992: 254)
\end{abstract}

WITH this tool I shall give birth to Art! (SpongeBob SquarePants: Artist Unknown)

For most of my years as an elementary music teacher I both named myself, and allowed myself to be named, an Orff or Kodaly teacher. The intensive training I received in these methods, both over several summers and a year-long programme, ingrained in me narratives that constituted my words and actions, indeed, my thinking, in and out of the classroom. I look back on those years and realise that even now, as I continue to interrogate and challenge these methods, they will forever be a part of me.

I recall those years and I am flooded with memories of 'my' students sitting in a semi-circle holding non-pitched instruments and Orff mallets in their hands. Memories of the step-by-step, from the 'known' to the 'unknown', of the articulated sequencing from body percussion to non-pitched instruments, practicing, presenting and building on the (seemingly always already) descending minor third and ta, ta, ti-ti, ta, fill me in ways of which I am not even cognisant. Physical responses are summoned within me that speak of animism, as I recall the rhythm cards and rhythmic/melodic dictation exercises, the pitch bars removed from instruments so that students sounded 'good' and could make no 'mistakes', the endless tools of production and processes of naming that determined (in

A version of this text was presented at The 5th International Conference for Research in Music Education, 10-14 April 2007, School of Education, University of Exeter. 
the context of 'school music') not only who we were to be musically, but what music was and could be. Wielding those tools of teaching that made me look knowledgeable and the students sophisticated in their musical knowings and understandings, I remember finding great contentment in this efficient process that brought command, product and respect. I was a successful music teacher, no doubt about it.

The purpose of this article is to think through Orff and Kodaly ${ }^{1}$ through the lens and conceptual notions of Karl Marx. Since Marx may not seem an obvious choice for an examination of music making, it makes sense to step back and consider my arrival at such an engagement. I was drawn to Marx because I had been reading authors who were products of Marxist thought. As many of these authors, such as Freire, Apple, Giroux, McLaren, Hooks, Althuser and others had framed much of my intellectual development, it made sense that I should read my way back to those ideas that had framed such an integral part of my thinking. This 'permission' I gave myself to read Marx as an 'expression of my life' (Marx, 1994: 107-8) framed a path of inquiry for examining what lay below the veneer and deceiving appearance of the 'rightness' and 'success' of the above-mentioned methods. This textual engagement with Marx also provided a mechanism for uncovering questions that I had never asked, but always seemed percolating at the surface. And lastly, this Marxist lens provided a way better to understand the power, fervency and seductive qualities that these music methods held not solely over me, but over many, many others.

Thus, as I entered Marx with the desire to 'read through' his thoughts and ideas, I grappled with his texts in hopes that I would connect and find 'previously unrecognised relations and similarities between ideas' (Bruner, 1960: 20). In fact, I remember the 'Ah hah!' moment when this first occurred. I had been reading a passage that spoke of those ways in which tools, having always been essential to individual creativity, became factorised, divided between many, and made part of a larger mode of production separating creator from product. Not such a staggering thought for anyone slightly familiar with 20th century development, and yet, this process of breaking down 'music' into small increments and dividing patterns between many struck me as similar to this process Marx was describing. And in that moment, I likened tools to those mallets my students had held in their hands and those ways in which I had made sure each individual was in charge of one ostinato pattern. Of course, breaking music down into individual parts isn't unheard of in the music-making process and indeed is integral to it in many cases; it was the way mallets and non-pitched instruments had become less music making materials and more like tools in a production line that struck me as similar to the division of labour Marx was writing about. It was also the particular inscription process of my presentation of the method that struck me as problematic; the semi-circle I provided for the students felt more like surveillance and management rather than music making. The sequencing and breaking down into 'manageable' parts felt to me like an operationalised philosophy of coercion, one in which bodies are 'subjected, used, transformed, and improved' (Foucault, 1984a: 180). And finally, it was the way in which for me the method had so often taken on an aura of fetish as the students simply became tools in the process.

Marx would suggest that history reflects who we are and how we are as people as made manifest in our modes of production. He would also suggest that who we are is also reflected in class antagonism and the struggle to garner equal shares in the fruits of the labour process, or in our case, the educative process. Through a Marxist lens, then, how 
might we consider the development of these music methods and the purpose of music education? How might music educators think through class antagonism and the ways in which legitimacy in the educative process can be equated to the idea of equal shares in the labour process? Even though the purpose of music education may not be a commitment to the socialism that Marx envisioned, music educators do have the potential to deliberately and consciously attend to issues of legitimacy, power, reproduction and maintenance that are potentially embedded in the indiscriminate embracing of methods and move toward envisioning what Marx would call a 'general reconstruction of society' and 'disappearance of class antagonism' (1977: 184). Quite possibly the disappearance of class antagonism may never come to pass, yet reproduction of fixed models can be interrogated and challenged. This, however, has much to do with interrogating one's self-deception and little to do with blaming others for one's determined path. Marx is helpful in rearticulating a purpose if we are willing 'to be undone by the critique that [we] perform' (Butler, 1995: 8) and continually reengage with the purpose of music education as one that is fluid rather than one that is fixed and provides stability. And while Marx provides one way of considering an unfolding of historical processes, this is not to suggest that a Marxist lens is above critique as a mode of inquiry. Interrogating issues of legitimacy, power and reproduction can serve as a guide toward revolutionary purposes that transcends the torment and affliction of control and class struggle. However, as a way to interrogate the field of music education's constant struggle with class antagonism as inscription and coercion, other critical voices, such as Butler and Foucault, also provide ways to address identity formation, complex issues, paradoxes and a reengagement with musicking as a 'free manifestation of life and an enjoyment of life' (Marx, 1994: 53).

\section{Carl Orff and Zoltan Kodaly}

Both Orff and Kodaly conceptualised their musical engagements as approaches and even as philosophy. Indeed, it can be posited that it is only the subsequent ritualisation, systematisation and codification of these approaches that have rendered them methods. That said, however, what both Orff and Kodaly borrowed from the work of philosophers, such as Rousseau and Pestalozzi, is often celebrated and made notable in the literature that surrounds and supports Orff and Kodaly in such a way as to suggest philosophical legitimacy beyond examination. Getting back to these philosophers' intent, then, serves to ground these methods in a broader context and moves us away from attributing to these ideas an 'independent existence ... without bother[ing] ourselves about the conditions of production and the producers of these ideas' (Marx \& Engels, 1978: 173). Foucault suggests, that rather than to find a beginning point or origin, the task of history is to jolt us into recognising 'the basis of [the] beginnings, atavisms, and heredities' (1984b: 80). Thus, as one familiarises oneself with the writings and musical processes of both Orff and Kodaly, as well as the websites of the national organisations of these methods, the 'basis' and 'heredity' embedded in Rousseau and Pestalozzi become apparent in ways that not only anchor these musical processes to these philosophers, but underscore the problematical nature of their precepts as well.

Rousseau (1956) referred to the educational system of his time as 'negative education' (p. 41), and believed that children must first engage freely with sensory impressions and 
ideas before being introduced to signs or representations: 'In any study whatever, the representing symbols mean nothing apart from the idea of the things represented' (p. 49). He believed that if one were to begin first with signs then students would be prevented from broader understandings. This belief was also reflected in how he construed the musical process, in that he was 'no more anxious to have [a child] learn to read music than to read writing' (p. 62) and that 'the only kind of lesson he should get is that of experience' (p. 40). Rousseau wrote rather extensively on how one should educate one's child musically. It is worth quoting him at length so that the basis of Orff and Kodaly become clearer.

First train your young musician in the making of regular phrases with well marked cadences; next get him to connect these phrases by a very simple modulation and then to indicate their different relations by a correct punctuation, through a fit choice of cadences and rests. Above all, avoid fantastic tunes and anything with pathos or forced expression. What is wanted in every case is a simple tuneful melody with the bass so clearly marked that he can feel and accompany it without difficulty. This means that for the training of voice and ear the child should always sing with the harpsichord. (Rousseau, 1956: 63)

Pestalozzi, whose own writings were also influenced by those of Rousseau, articulated his 'laws of teaching' (Pestalozzi, 1894: 199) in such a way that one also is able to consider the direct correlation between his views and those of Orff and Kodaly. Among those laws:

- Arrange all objects in the world according to their likeness.

- Strengthen the impressions of important objects by allowing them to affect you through different senses.

- In every subject try to arrange graduated steps of knowledge, in which every new idea shall be only a small, almost imperceptible addition to that earlier knowledge which has been deeply impressed and made unforgettable.

- Learn to make the simple perfect before going on to the complex (p. 202).

Clearly, if one has a working knowledge of Orff or Kodaly, one recognises in the above quotes the 'beginnings, atavisms, and heredities' of their philosophical conception of the musical process. For example, both Orff and Kodaly believed that experience must precede symbol, reinforcing both Marx and Rousseau's idea that knowledge and facts found in books determined how we could think. Integral to this process of experience was, for both, the importance and even necessity of improvisation. However, theirs was not a process conceived of as improvisation bound by assembly-line constraints nor of controlled environments and clearly delineated divisions of labour, often made arbitrary by the key of 'folk music', and the (often limiting) melodic, rhythmic and harmonic framework that frames the folk tune. Additionally, both Orff and Kodaly believed that learning would best occur if the simple preceded the complex, and envisioned the learning process as one that needed to be broken down into small fixed steps (with subsequent elements being added systematically only when the student is 'ready'). With the intent that the music content be that of the child's 'culture', these steps suggest movement from musically simple to the musically complex, encompassing both melodic and rhythmic structures of 'folk music of the mother tongue', rather than 'fantastic tunes'. This, however, meant (and means) the possibility of not only disregarding the musical palate of students, but more and more to 
ignore the students' increasingly sophisticated sonorous and technical understandings of musics rooted in vast and multiple cultures and technologies.

And finally, primary to the process (or production) is the use of tools in the form of solfege syllables, hand signs, speech, body percussion, non-pitched and pitched instruments. While neither Orff nor Kodaly attribute their use of these to the influence of Pestalozzi and Rousseau, the centrality of tools, albeit understood differently, plays a fundamental role in Pestalozzi and Rousseau's construction of the social development of humans. Pestalozzi's formulation of education was based on activity rather than book learning, thus tools, and the use of tools, clearly played an integral part in his conception of the educative process. But it is the influence of Rousseau, upon whom Marx's thinking can be directly traced, to which we must turn. In his contemplation of natural law, inequality, and consequently, private property, Rousseau (1754) speaks of the role of implements, or tools, in the development of land and of shelters. He believed that private property led to society's inability to preserve balance and posited that it was through the development of implements and consequently the idea of private property from which the root of societal, or civil 'evil' can be traced. And while it may not seem evident that the solfege and hand-signs are tools in the sense of how one might consider the hammer to be, the purposeful, methodical use of these suggests tools that can be and are often used toward a particular functional and efficient end, thus rendering places of musical and creative possibilities as possible sites of private property, management, control and limitations.

The process and production of these methods is one in which the 'problem' (and hence, 'success') is defined as guided musical engagement, making it possible to address how to move toward that goal, and consequently whether the student is progressing toward (or has achieved) that goal. All of which speaks to a scientific and technocratic model of education with 'delineated content, predefined skill acquisition, sequential instruction, [and] teacherproof procedures' (Hamblen, 1985: 2). So while the intent may be to involve children in a process of musical engagement that is self-expressive and creative, the tools of these modes of production, including a particular 'folk language', can actually be used in such a way that alienates the students from a conception of musicking Orff and Kodaly envisioned. Thus, it is not just the musical presentation that almost always appears sophisticated, persuasive and winning that becomes a commodity, it is also the approach or method, as a mode of production, that ends up being exchanged as a commodity.

In the following section, I present a brief overview of some basic Marxist concepts that will serve to set up both the idea of methods as a mode of production and as a lens through which to consider the shift from the use-value of musicking, that both Orff and Kodaly desired, to that which functions as exchange-value commodity for both student and teacher.

\section{Use-Value Exchange-Value and Modes of Production}

I am interested in [the work of Marx] because some of his analyses and concepts tell us a good deal about who we are, where we are, and how we might change who and where we are. (Critchley, 2008: 12) 
How we might change where we are in the educative process is a constant advocacy concern of music education organisations. However, how we might change who we are ranks much lower in the hierarchy. Consequently, one way Marx can inform our work is as a lens through which we can begin to determine who we are and how we have come to be. The widespread, almost universal acceptance of Orff and Kodaly as teaching methods is simply one manifestation of what I see as a struggle for recognition and worth in the educative process. My concern with the use of these methods, then, is two-fold. One, with their systematised structure of order and sequence they take the place of critical thought and agency, and two, in the process of self-estrangement from the kinds of problem posing found in musicking situations that are less clearly delineated by sequential ordering, both students and teachers become alienated from themselves. Therefore, Marx also provides a lens through which to consider the history of music education as the history of becoming alienated from bringing into being that which we love. In German Ideology, Marx and Engels begin to articulate their conception of history.

The first premise of all human history, of course, is the existence of living human individuals ... The first fact to be established, then, is the physical organization of these individuals and their consequent relationship to the rest of nature. (Marx, 1994: 107)

History, for Marx and Engels, begins with the process of satisfying basic needs that arise in our existence as natural, social beings. Fulfilling these needs, which requires 'the action of satisfying and the acquisition of the instrument for this purpose' (Marx, 1994: 115-16) creates new needs. Thus, embedded in the process of satisfying needs is the construction of new tools, mechanisms, methods, etc., necessary to realise the new needs. For Marx, the production of new needs is the first historical act and it is the differing and evolving modes of production, or activities, that determine social life and human history. These modes of production, which in Marx's view, are controlled by those who have the 'means of material production at its disposal' (1978: 172), represent all forms of human activity (including art) and must not be viewed simply as the reproduction of human life, but rather as an expression of life, and thus, of who we are. Therefore, who humans are is 'dependent upon the material conditions that 'determine' the production' (p. 108), as well as dependent upon those who control those conditions. Consequently, what and who we are (and become) is thus intertwined with not only what and how we produce, but who controls the means of the production.

Even for those who are not Marxist scholars or critical theorists, considering music as a commodity takes little effort. In fact, and unfortunately, the normalcy of this word distances us from attending to the human agency of this construct. However, even at the most rudimentary level, most people would agree that music can be, has been, and often is, exchanged for something other than personal enjoyment and pleasure. Atalli (1985) traces the path of music as a commodity and identifies the beginning point as the 19th century. 'Among sounds, music as an autonomous production is a recent invention. Even as late as the eighteenth century, it was effectively submerged within a larger totality ...' (p. 3). However, music as a commodity can be traced back to the first organised sounds humans produced as something simply of use-value that would satisfy what Marx referred to as the human characteristics of social and creative expression. Elliott (1995) writes that musicking, 
as a 'strangely impractical endeavor' (p. 109), does not appear to satisfy a biological need: 'Homo sapiens is the species that 'musics"' (p. 109). And while music does not serve to satisfy hunger, thirst or provide shelter, the making of music can be viewed as subsistence, a 'thing' or process that satisfies social and creative needs. Small (1998) would say, as music is not a 'thing, but an activity, something that people do' (p. 2), it makes sense that people would find great use and do this 'thing' together socially, and in the process create new processes, or modes of production and ways of 'musicking'. Music, or musicking in this case, may be exchanged for fulfilment and pleasure, but not exchanged in ways that deny the musicker agency and presence in the process.

Thus, music as a commodity is not a 'bad thing' in and of itself, not as long as its use-value brings satisfaction for a basic human need. For Marx, a commodity is,

first of all, an external object, a thing which through its qualities satisfies human needs of whatever kind. The nature of these needs, whether they arise, for example, from the stomach, or the imagination, makes no difference. Nor does it matter here how the thing satisfies man's need, whether directly as a means of subsistence, i.e. an object of consumption, or indirectly as a means of production. (1977: 125)

It is only when the commodity becomes exchanged for something other than the satisfaction of basic needs that it begins to mask, deny and disregard the relation of the person to the process of creation. In the case of music methods, musicking morphs into an exchange value when the worth and systematic process of the methods, or the mode of production, and thus the performance, is used in exchange for something other than use value. Hence, what we need to consider and what is at the heart of this discussion, is what this exchange brings; for what, and to whom? In the case of music and music education, a discipline that has never been considered basic to the educative process, these methods, that often produce controlled and managed classrooms, seemingly sophisticated performances that appear to 'work' for all, are used as exchange for legitimacy in the educative process.

Thus, the exchange-value of performance (and the mode of production) is legitimate or of equal value to that of other disciplines and their ways of knowing and being able to do, only if the time and effort, or the labour-time, is the same in its production, and equal, or 'have therefore the same value' (Marx, 1977: 130) to those of the 'basics'. Consequently, traditions and rituals such as competition, higher awards, superior ratings - all of which must be pursued with blind intensity, furthering the division of labour and the alienation process that separates students from the use value of musicking - have the same value in an educative process that is marked by measurability and accountability. However, it is not only student/musicians who are alienated from the educative process and possible dialogue of interrogation with the teachers. The teachers, who presume to own the mode of production, are in reality alienated from the educative process as they are, in reality, handmaidens to a discourse of normative and commonsense social production of what counts as knowledge and unfortunately, in many cases, what counts as music.

In the quest for a performance that reflects established 'quality' repertoire, and thus cultural capital and legitimacy, the labourer (student/musician) is a cumbersome necessity. With the preferred outcome of a performance that seems to transcend the necessary requisite of the student/musician, the labourer (student/musician) is abstracted from their use-value, indeed, expendable. Thus, the performance and the mode of production, 
takes on the fetishism of a product that is seemingly produced without human agency. Methods become more real than the music and the student/musician's worth is that of their exchangeability. As such, as Ollman (1976) points out, '[This] product, which is meant to satisfy human needs, serves instead to re-order the lives of the people who come into contact with it, getting them to act in ways that affirm its character as a capitalist product' (p. 200). This product, that speaks to fulfilment of one of our most basic social needs, reorders the lives of teachers and students constructing also that which becomes 'school music'. Unfortunately, the desiring of legitimacy, which has been shaped by the existential situation of the status of music education and music teachers, crafts and presents 'right' and 'true' (false) choices that present themselves as the only way, the only answer, for what a music programme in an age of measurability and accountability can be. Considering Marx, Wood (2004) points out that,

Those... who choose methods of production which maximize profits will survive and flourish; those who make different choices will lose their capital and the social power it represents. (p. 47)

Compliant and obedient, we so often see these methods as our only choice, as ways to bolster and save the profession and our students; methods as salvation. This 'choice' is not only a non-choice, but what Noddings (1992) would say is 'morally wrong and pedagogically disastrous' (p. 154). If, then, as Marx suggests, that what we are is what and how we produce, what of these methodological choices and how have they conditioned us as educators and as humans? In German Ideology (1994) Marx writes that 'Consciousness does not determine life, but life determines consciousness' (p. 112). For Marx, embedded within living life and freedom is an expected agency that indeed determines consciousness; an agency that challenges and interrogates ideology that produces false consciousness, so that we might disrupt 'false conceptions of [ourselves], about what [we] are or what [we] ought to be' (Marx, 1994: 103). Agency, in many ways, means active disruption and constant interrogation of the choices (and non-choices) we make. It is to unmask the self-alienation that comes from the most base level of survival grounded on production.

\section{How method functions}

Does our teaching, our use of particular sets of practices and forms of discussion, subjugate? (Britzman, 1992: 257)

Foucault (1980), in writing of the 'how of power' (p. 92) asks the question, 'what rules of right are implemented by the relations of power in the production of discourses of truth' (p. 93)? Foucault suggests that it's not just the legitimacy issues embedded in 'right' at which we should be looking or considering, but rather what 'methods of subjugation' are being instigated in the name of right (p. 96). If we use Marx to challenge methods as a discourse of truth - in which 'right' musical engagements could be construed as private property, enslaving and owning both teacher and student - we are then able to consider the ways in which teacher and student/musician is subjugated through this mode of production; alienating both student and teacher from the music making and reproducing a larger educative process that is intent on doing the same. Methods, conceived of as 
private property, do not actualise or engender relationships that are sustained by use-value engagements, or concrete interactions that engage and fulfil creative expression. Rather, as Rousseau believed, private property serves to incite hunger and greed that corrupts and deflects the ability to see ourselves as a whole and thus, not only divides human interests as a community, but acts for Marx, as a 'denial of freedom' (Brenkert, 1979: 126).

While Marx (1994) was not the first to speak of religion as an opium for the people, it is he who is often remembered for calling our attention to the ways in which the creation and search for religion is a manifestation of human suffering tethered by the realities of the world. Religious suffering is at once a reflection of 'real suffering and yet at the same time a protest against' (p. 28) the conditions of that suffering. The constraints of many of our teaching realities are those in which suffering is indeed a part of the lives of our students. I am certainly not suggesting or equating the suffering endured by many peoples in this world to those of music educators who are culpable and complicit in how they shape and have been shaped by the conditions and contradictions in which they have found themselves. Consider that music methods have not only functioned as religion through and in which teachers find comfort, but as a universal language where music methods are 'colour blind' and seen as a way to 'even the playing field' for students. Regelski has written of the engagements with the doctrine of these methods as 'coming close to the worship of religious idols', and refers to this practice as 'methodolatry' (2005: p. 13). Marion Flagg writes of the 'consoling appeal' of Orff in 1966, right around the time Orff was becoming ingrained in the fabric of American music education.

The simplicity of the Orff approach has the consoling appeal that the complexities of living in today's world can be pleasantly and safely ignored. Would that it were so! Everything around and within the music education profession tells us otherwise-that we must catch on and catch up, not matter how complex, disturbing, and terribly exciting this new world of simultaneous relations is. (Flagg, 1966: 30)

Few would dispute that the contradictions of the world are such that it is both complex and disturbing. But is there also 'musical suffering?' Can this desire and need for method be considered an opium? Is method our 'sigh of the oppressed creature' and a manifestation of 'illusory happiness' (Marx, 1994: 28)? I would suggest that not only has worship of method made 'success' illusory and thus prevents critical engagement with consciousness, method also serves as a mode of domination that functions as a way to reproduce divisions that alienate us from the very musical engagements that can and ought to bring humans use and satisfaction.

Neither Orff nor Kodaly referred to their approaches as methods, and they certainly never referred to them as ideology. Yet, it is the 'production and representation' (Darder et al., 2003: 79) of meaning, and particular views and ritual practices, and the way in which they often function as 'apparatuses of control' (Foucault, 1980: 102), as well as the common-sense element and irrefutable world view embedded in these methods (they 'work') that renders them ideology. The particular, predetermined end-point these methods serve and the power structures they mask, the assumption that literacy is an integral element of what it means to be a musician and for Kodaly thus, a 'better human being' (Kodaly, 1967: 3), and the cultural capital these methods preserve, through the exploitation of not only the student/musician but the music teacher as well, seem very much to be 
representative of the social problems that lead to what Regelski would refer to as 'of the most profound pragmatic character' (2005: 7).

In a world in which access and equity are the current siren call, it behoves us to consider who benefits from what we do, so that the definition of equity and access as providing those that don't have, with the cultural capital and materialistic 'things' that might suggest 'having', and consequently being, is interrogated and challenged. Equity is the critical consciousness necessary to challenge exiting ideologies, propaganda and systems of inequity. It is not an equal chance to embrace the status quo and succeed at a capitalistic version of the American Dream, but rather agency and empowerment to 'achieve active and rewarding musical lives of [our] choice' (Regelski, 2005: 16).

\section{Some lingering thoughts}

Bowman (1998) cautions that the production of a commodity 'transforms relations between people into relations between things, and people's lives become increasingly defined by the exchangeability of the commodities they produce' (p. 309). These methods, and the music that is often produced in the systematic engagement with the method, estrange us from an educative process that celebrates creativity and intelligence and can lead us toward, in Marx's (1978) construction, 'deformity... idiocy, cretinism' (p. 73). History, for Marx, is this process of estrangement; not only manifested in the product but 'in the act of production - within the producing activity itself' (p. 73). If what we do and love as a basic fulfilment of a human need is used and exchanged for something outside of our critical and reflective engagement then this particular production, and others like it, need to be questioned.

Toward the beginning of the paper I referred to Marx's vision of a 'general reconstruction of society' and the 'disappearance of class antagonism' (p. 184). The indiscriminate use of method, any method (including those that may dictate rehearsal techniques and practice techniques) deflects our attention from interrogating issues such as what our purpose would be if a reconstruction of society based upon critically reflective learning framed our engagements. It is not the concept of these methods that needs to be done away with; both Orff and Kodaly envisioned musical processes that sprang from the innate desire to experience and create as a social, musical engagement. Rather, it is a need to interrogate the indiscriminate embracing of these methods as a possible form of control and coercion, as well as the possible appropriation of musicking as a way to increase the social capital of music teachers. It is to imagine that these methods can and have been used as a mode of production in which the division of labour alienates both teacher and student from a form of musicking that, as Marx \& Engels (1978) suggest, 'does not belong to [our] essential being' (p. 74). It is to consider multiple contexts as varied as, policy and advocacy efforts, garage band models, quartets and chamber ensembles, that condition our existence and either shape or hinder the possibilities of freedom and fulfilment found in thinking in practice, indeed, musicking, as a call to revolution. It is not just to become more aware, or more critical, but to consciously attend to our own agency as we continually adjust, adapt, rethink and reengage. Marx (1994) speaks of the difficulty embedded in the complexity of this process, and while he refers specifically to religion his words apply to any condition 
and process that binds and prevents us from 'revolting' against the present conditions of life:

The abolition of religion as people's illusory happiness is the demand for their real happiness. The demand to abandon illusions about their condition is a demand to abandon a condition which requires illusions. (p. 28)

Would that I could sum this paper up into a nice tidy ending, with something such as, 'Music teachers of the world unite and demand an end to these conditions'. Unfortunately, this reactionary (rather than revolutionary) call seems already ingrained in our profession and has done little to lead us out of models of reproduction and stasis; 'loosing our chains' isn't really something we are prepared to do. Heilbroner (1980) reminds us that a 'Marxian approach to philosophy stresses the production, rather than the passive receipt of knowledge - the involvement of the act of inquiry in shaping, as well as in discovering, knowledge' (p. 31). As our field moves further into discussions that consider political, social and economic aspects, as we attempt to envision music education connected to larger elements of life, and question modes of production as process and sequence that elicit subjugation, what would really be revolutionary would be to abandon illusions of consensus, illusions of worth and illusions of salvation.

\section{Note}

1 I choose Orff and Kodaly to situate this investigation because of my intimate knowledge with them and because as they were conceived they lend themselves to analysis of this nature. However, the ordering of the body and the physical embodiment of music toward a very specific goal within a Dalcroze approach could also be examined through this framework, as could The Gordon Music Learning Theory and its 'comprehensive method for teaching musicianship' (The Gordon Institute for Music Learning). The constraints of this paper do not permit an in-depth examination of these approaches.

\section{References}

ATALLI, J. (1985) Noise: The Political Economy of Music. Minneapolis, MN: University of Minnesota. BOWMAN, W. (1998) Philosophical Perspectives on Music. New York, NY: Oxford University Press. BRENKERT, G. (1979) 'Freedom and private property in Marx', Philosophy and Public Affairs, 8 (2), 122-147. BRITZMAN, D. (1992) 'Structures of feeling in curriculum and teaching', Theory into Practice, 31 (3), 252-258.

BRUNER, J. (1960) The Process of Education. Cambridge, MA: Harvard University Press.

BUTLER, J. (1995) 'Conscience doth make subjects of us all', Yale French Studies, 88, Depositions: Althuser, Balibar, Macherey, and the Labor of Reading, 6-26.

CRITCHLEY, S. (2008) Infinitely Demanding: Ethics of Commitment, Politics of Resistance. New York, NY: Verso.

DARDER, A., BALTODANO, M. \& TORRES, R. (Eds). (2003) The critical pedagogy reader. New York, NY: Routledge-Falmer.

ELLIOTT, D. (1995) Music matters: A new philosophy of music education. New York, NY: Oxford University Press.

FLAGG, M. (1966) The Orff System in today's world. Music Educators Journal, 53 (4), 30.

FOUCAULT, M. (1980) Power/knowledge: Selected interviews and other writings 1972-1977. New York, NY: Pantheon Books. 
FOUCAULT, M. (1984a) 'Docile bodies', in P. Rainbow (Ed.), The Foucault reader. New York, NY: Pantheon Books.

FOUCAULT, M. (1984b) 'Nietzsche, genealogy, history', in P. Rainbow (Ed.), The Foucault reader. New York, NY: Pantheon Books.

HAMBLEN, K. (1985) 'The issue of technocratic rationality in discipline-based art education', Studies in Art Education, 27 (1), 43-46.

HEILBRONER, R. (1980) Marxism: For and against. New York, NY: W. W. Norton \& Company.

KODALY, Z. (1967) 'Folk song in pedagogy', Music Educators Journal, 53 (7), 59-61.

MARX, K. (1977) Capital (Vol. 1). New York, NY: Vintage Books Edition.

MARX, K. \& ENGELS, F. (1978) 'Economic and philosophic manuscripts of 1844 (2nd edn)', in R. C. Tucker (Ed.), The Marx-Engels reader (pp. 66-125). New York, NY: W.W. Norton \& Company.

MARX, K. (L. H. Simon, Ed.) (1994) Karl Marx: selected writings. Indianapolis, IN: Hackett Publishing Company, Inc.

NODDINGS, N. (1992) The challenge to care in schools. New York, NY: Teachers College Press.

OLLMAN, B. (1976) Alienation: Marx's conception of man in capitalist society (2nd edn). Cambridge: Cambridge University Press.

PESTALOZZI, J. H. (1894) How Gertrude teaches her children. Translated by L. E. Holland and F. C. Turner. New York, NY: Gordon Press.

REGELSKI, T. (January, 2005) Critical theory as a foundation for critical thinking in music education. Visions of Research in Music Education, 6, 1-25.

ROUSSEAU, J. (1754) 'A discourse on a subject proposed by the Academy of Dijon: What is the origin of inequality among men, and is it authorised by natural law'. Retrieved 23 January 2009, from the Constitution Society in the Rousseau site http://www.constitution.org/jjr/ineq.htm

ROUSSEAU, J. (1956) The Emille of Jean Jacque Rousseau Selections. Translated by W. Boyd. New York, NY: Teachers College Press.

SMALL, C. (1998) Musicking: The meaning of performing and listening. Middletown, CT: Wesleyan University Press.

WOOD, A. (2004) Karl Marx (2nd edn). New York, NY: Routledge.

YOUNG, P. M. (1976) Zoltan Kodaly: a Hungarian musician. Westport, CT: Greenwood Press. 